\title{
Correction to: (Epoxidized castor oil - citric acid) copolyester as a candidate polymer for biomedical applications
}

\author{
Natalia L. Parada Hernandez ${ }^{1}$. Juliana O. Bahú ${ }^{1}$ - Maria Ingrid R. B. Schiavon ${ }^{1}$. Anderson J. Bonon ${ }^{1,2}$. \\ Cibelem I. Benites ${ }^{3} \cdot$ André L. Jardini $^{1} \cdot$ Rubens Maciel Filho $^{1} \cdot$ Maria Regina Wolf Maciel $^{1}$
}

Published online: 19 July 2019

(C) The Polymer Society, Taipei 2019

\section{Correction to: Journal of Polymer Research https://doi.org/10.1007/s10965-019-1814-5}

The original version of this article unfortunately contained a mistake. The name "Maria Regina Wolf Wolf Maciel" should be corrected to" Maria Regina Wolf Maciel".

The original article has been corrected.

Publisher's note Springer Nature remains neutral with regard to jurisdictional claims in published maps and institutional affiliations.

The online version of the original article can be found at https://doi.org/ 10.1007/s10965-019-1814-5

Juliana O. Bahú

juliana.bahu@gmail.com

1 National Institute of Science and Technology in Biofabrication (BIOFABRIS) - School of Chemical Engineering, University of Campinas, Av. Albert Einstein, 500, Campinas, SP 13083-852, Brazil

2 HORIBA Scientific, 9755 Research Dr, Irvine, CA 92618, USA

3 Department of Agriculture, Livestock and Food Supply, National Agricultural Laboratory (LANAGRO-SP), Raul Ferrari Street, Campinas, SP 13100-105, Brazil 